\title{
KEMAMPUAN GURU MIPA MEMBUAT PENILAIAN PENGETAHUAN
}

\author{
Kurnia Ningsih \\ Dosen Pendidikan Biologi FKIP Universitas Tanjungpura, Pontianak \\ E-mail: nia_untan@yahoo.com
}

\begin{abstract}
This research aims to describe MIPA teachers' ability to design knowledge assessment through the analysis of achievement aspects of knowledge assessment. This research used a descriptive method with SMP MIPA teachers in Pontianak City who have taught for more than 5 years and have an undergraduate degree as the population. The samples in this research, selected using a purposive sampling technique, consisted of 12 teachers who submitted MIPA test items. The research instrument used the data of the test item document designed by the teachers in the form of a multiple-choice test. The data were analyzed descriptively which included data reduction, systematic data display, and conclusion. The results showed that of the 12 test instruments made by with 380 questions in total, the teachers' ability to design knowledge assessment (Multiple Choice Questions) obtained $17.37 \%$ of knowledge aspect, $67.90 \%$ of understanding aspect, $8.68 \%$ of implementation aspect, and $6.05 \%$ of analysis aspect. There were no questions made related to evaluation and creation aspects.
\end{abstract}

Keywords: teachers ability, designing knowledge assessment.

Salah satu tugas utama guru adalah melakukan penilaian (asesmen) pada peserta didik. Dalam menilai peserta didik, hendaknya guru melakukannya dengan cara yang tepat dan obyektif. Dengan memberikan penilaian yang tepat, guru akan mengetahui kemajuan peserta didik dalam pencapaian kompetensi yang diinginkan. Menurut Mardapi (2012), penilaian merupakan bagian dari evaluasi program pembelajaran. Guru harus mempunyai kemampuan untuk mengevaluasi yang mencakup: (1) melaksanakan tes, (2) mengelola hasil penilaian, (3) melaporkan hasil penilaian, dan (4) melaksanakan program remedial/perbaikan pengajaran (Subroto, 1997). Dalam melakukan kegiatan penilaian, seorang guru harus memerhatikan tujuan pembelajaran yang telah ditetapkan. Sehingga dapat dikatakan guru merupakan salah satu faktor penentu keberhasilan pendidikan. Keberhasilan pendidikan tentunya tidak terlepas dari kinerja guru dalam merencanakan, melaksanakan, menilai dan mengevaluasi peserta didik.

Berdasarkan Peraturan Pemerintah Nomor 66 Tahun 2013 menyatakan bahwa penilaian hasil belajar dilakukan oleh pendidik, satuan pendidikan, Pemerintah dan/atau lembaga mandiri. Penilaian hasil belajar oleh pendidik dilakukan secara berkesinambungan untuk 
memantau proses, kemajuan, dan perbaikan hasil dalam bentuk ulangan harian, ulangan tengah semester, ulangan akhir semester, dan ulangan kenaikan kelas. Penilaian yang dilakukan pendidik digunakan untuk menilai pencapaian kompetensi peserta didik, bahan penyusunan laporan kemajuan hasil belajar, dan memperbaiki proses pembelajaran.

Selain itu, penilaian hasil belajar oleh pendidik menggunakan berbagai teknik penilaian berupa tes, lembar observasi, penugasan perseorangan atau kelompok dan bentuk lain yang sesuai dengan karakteristik kompetensi dan tingkat perkembangan peserta didik (Arikunto, 2008). Teknik tes yang dimaksud berupa tes tertulis, tes lisan, dan tes praktik atau kinerja. Penilaian hasil belajar berupa tes, observasi atau pengamatan, dan penugasan individual maupun kelompok seharusnya dilakukan guru sebagai kinerja dalam pencapaian profesionalitas. Tetapi kenyataan dilapangan masih belum maksimal dalam pelaksanaannya.

Berdasarkan hasil observasi terhadap 10 orang guru SMP yang mengajar IPA (November 2014) diperoleh $50 \%$ guru dalam merumuskan aspek penilaian (soal evaluasi) pada perencanaan pelaksanaan pembelajaran yang dibuat guru, masih belum relevan antara tujuan pembelaran/ indikator soal dengan soal, dan belum tepat dalam menentukan aspek penilaian yang diukur.

Salah satu contoh yang ditemukan dilapangan, tentang ketidaksesuaian antara indikator dengan soal yang dibuat adalah sebagai berikut:

Indikator: Membedakan gejala alam, kejadian dan kebendaan obyek biotik dan abiotik melalui pengamatan, dengan aspek yang diukur adalah pemahaman (C2).

Soal: Yang merupakan komponen biotik berikut ini adalah....
a. Makhluk hidup
b. Benda mati
c. Makhluk bersel satu
d. Multi sel

(Dokumen Pribadi, November 2014)

Seperti pada contoh indikator dan soal yang dibuat guru, dapat dicermati bahwa pada indikator menginginkan soal yang dibuat dapat mengukur kemampuan siswa untuk membedakan gejala alam, kejadian dan kebendaan obyek biotik dan abiotik melalui pengamatan. Dari indikator tersebut, seharusnya peserta didik diminta untuk melakukan pengamatan, dalam hal ini menuntut aspek kinerja, tetapi soal yang dibuat mengukur aspek pengetahuan. Aspek pengetahuan yang diukur, hanya pada aspek pengetahuan (kognitif) mengingat komponen biotik. Selain itu pilihan jawaban (option) masih belum homogen, pertanyaan/soal (stem) masih menggunakan kalimat tidak baku. Jika ditinjau dari aspek yang diukur. soal yang dibuat guru masih pada aspek pengetahuan kognitif ingatan (C1).

Hal ini sesuai dengan hasil penelitian yang dilakukan oleh Suryana, Fachrudin, dan Ustman (2010), tentang pelatihan asesmen dan evaluasi pembelajaran untuk peningkatan kemampuan professional bagi tutor kejar paket B kesetaraan pada pusat kegiatan belajar masyarakat (PKBM) di kota 
Semarang dari 40 orang peserta diperoleh; kemampuan dalam penguasaan teori asesmen dan evaluasi hasil belajar secara berturutturut mulai dari kategori baik sekali, kategori baik, dan kurang adalah $50 \%$, 40\%, dan 10\%. Menurut Sudrajat (2012), penilaian (assesment) adalah penerapan berbagai cara dan penggunaan beragam alat penilaian untuk memperoleh informasi tentang sejauh mana hasil belajar yang telah ditentukan. Hasil penilaian dapat berupa nilai kualitatif (pernyataan naratif dalam kata-kata) dan nilai kuantitatif (berupa angka) (Anwar dan Hendra, 2011).

Penilaian dapat diartikan sebagai suatu proses memberikan nilai kepada objek tertentu berdasarkan suatu kriteria (Ratumanan dan Laurens, 2011). Penilaian dapat dipengaruhi oleh hasil Pengukuran (Changelosi, 1990). Untuk dapat menentukan nilai suatu objek diperlukan adanya ukuran atau kriteria. Misalnya untuk dapat mengatakan baik, sedang, dan kurang diperlukan adanya ketentuan atau ukuran yang jelas bagaimana yang baik, sedang, dan yang kurang tersebut.

Anderson dan Krathwohl (2010) menyatakan bahwa: "dimensi proses kognitif (pengetahuan) meliputi: mengingat, memahami, mengaplikasikan, menganalisis, mengevaluasi, dan mencipta". Mengingat adalah mengambil pengetahuan dari memori jangka panjang. Memahami adalah mengkonstruksi makna dari materi pelajaran, termasuk apa yang diucapkan, ditulis dan digambar oleh guru. Mengaplikasikan adalah menerapkan atau menggunakan suatu prosedur dalam keadaan tertentu. Menganalisis adalah memecah-mecah materi jadi bagian-bagian penyusunnya dan menentukan hubungan antar bagian dan bubungan antara bagian tersebut dan keseluruhan struktur atau tujuan. Mengevaluasi adalah mengambil keputusan berdasarkan kriteria dan/atau standar. Mencipta adalah memadukan bagian-bagian untuk membentuk sesuatu yang baru atau untuk membuat suatu produk yang orisinil. Berdasarkan indikator soal yang terdapat pada standar kompetensi lulusan (SKL) tentunya seorang guru harus dapat menjabarkarnya dalam butir soal yang menggambarkan indikator tersebut. Dengan demikian penilaian pengetahuan dalam pembelajaran MIPA dapat berupa penilaian pengetahuan yang dibuat oleh guru meliputi aspek: mengingat, memahami, mengaplikasikan, menganalisis, mengevaluasi, dan mencipta.

Sedangkan tuntutan standar kompetensi lulusan (SKL) yang di dalamnya terdapat indikator soal, menginginkan kemampuan kognitif yang diukur sampai pada menganalisis, mengevaluasi, dan mencipta atau sering disebut dengan aspek C4, C5, dan C6. Anderson dan Krathwohl (2010) menyatakan bahwa, selain dimensi proses kognitif yang meliputi; mengingat, memahami, mengaplikasikan, menganalisis, mengevaluasi, dan mencipta, perlu diperhatikan tipe pengetahuan dalam proses pembelajaran. Tipe pengetahuan ini meliputi; pengetahuan faktual, pengetahuan konseptual, pengetahuan 
prosedural, dan pengetahuan metakognitif. Jadi dalam menentukan standar kompetensi kelulusan perlu diperhatikan apakah kompetensi yang diharapkan sudah sampai pada aspek dimensi menganalisis dengan tipe pengetahuan yang masih faktual dan konseptual, atau sudah sampai pada pengetahuan prosedural dan pengetahuan metakognitif. Berdasarkan indikator soal yang terdapat pada standar kompetensi lulusan (SKL) tentunya seorang guru harus dapat menjabarkarnya dalam butir soal yang menggambarkan indikator tersebut.

Dari apa yang telah dipaparkan sebelumnya, maka perlu dilakukan penelitian lebih mendalam tentang deskripsi kemampuan guru MIPA dalam membuat penilaian pengetahuan. Adapun manfaat hasil penelitian ini adalah memberikan gambaran tentang kemampuan guru MIPA dalam membuat penilaian, sehingga akan menjadi masukan pada guru dalam membuat soal yang berkualitas, dan akhirnya dapat meningkatkan prestasi belajar siswanya.

\section{METODE}

Metode penelitian yang digunakan adalah metode penelitian deskriptif. Penelitian deskriptif adalah penelitian yang dilakukan terhadap variabel mandiri, yaitu tanpa membuat perbandingan, atau menghubungkan dengan variabel yang lain (Sugiyono, 2008). Penelitian ini dilakukan untuk mendeskripsikan atau menggambarkan keadaan sesungguhnya kemampuan guru dalam membuat penilaian pengetahuan.
Adapun prosedur penelitian yang dilakukan dalam penelitian ini adalah: (1) menentukan populasi penelitian, (2) mentukan sampel penelitian, (3) memperoleh data penelitian melalui dokumen soal yang dibuat oleh guru, (4) analisis data hasil penelitian, (5) menyimpulkan hasil penelitian, dan (6) membuat laporan penelitian.

Populasi dalam penelitian ini adalah guru MIPA di SMP Kota Pontianak, baik yang berasal dari sekolah negeri maupun swasta. Adapun karakteristik populasi dalam penelitian ini adalah mempunyai kriteria telah mengajar lebih dari 5 tahun, pendidikan terakhir S-1, mempunyai sertifikat pendidik (sertifikasi), dan menyerahkan perangkat soal yang dibuat. Pengambilan sampel dilakukan dengan menggunakan teknik purposive sampling yaitu sampel yang diambil berdasarkan tujuan peneliti (Sugiyono, 2008). Adapun sampel dalam penelitian ini adalah 12 orang guru yang menyerahkan dokumen soal MIPA.

Instrumen penelitian yang digunakan sebagai alat pengumpul data adalah data dokumentasi soal MIPA. Data dokumentasi bertujuan untuk mencari data soal ulangan yang dibuat guru untuk menggali kemampuan guru membuat penilaian pengetahuan berdasarkan aspek pengukuran penilaian pengetahuan peserta didik.

Setiap alat pengumpul data harus mempunyai kesahihan (valid) dan keterandalan (reliabel) agar dapat digunakan sebagai alat pengumpul data yang baik (Djaali, 2008). Data dokumentasi soal yang dibuat guru telah dilakukan pengujian validitas 
dan reliabilitas dengan menggunakan valiidity content melalui expert judgement, yaitu dengan melihat kesusuaian atara indikator dan soal yang dibuat, dan didiskusikan dengan teman sejawat.

Jenis data yang diperoleh dalam penelitian ini yaitu data kualitatif. Data kualitatif dianalisis dan diinterpretasikan sesuai dengan kebutuhan penelitian. Data yang diperoleh dianalisis dengan analisis deskriptif meliputi tahapan: reduksi data, penyajian data secara sistematis, dan penarikan kesimpulan.

\section{HASIL DAN PEMBAHASAN}

Hasil penelitian ini mendeskripsikan kemampuan guru Matematika dan IPA (MIPA) membuat penilaian pengetahuan di SMP Kota Pontianak. Berdasarkan hasil dokumentasi soal ulangan yang dibuat guru diperoleh data, kemudian dilakukan reduksi data dengan mengelompokkan soal yang telah dibuat guru pada aspek yang diukur. Kemudian soal ditelaah dan disesuaikan dengan aspek yang diukur pada masing-masing bidang Matematika dan IPA. Selanjutnya data dianalisis dengan menghitung persentase dari setiap perangkat soal yang dibuat dengan aspek yang diukur.

Berdasarkan hasil analisis data dokumentasi soal ulangan yang dibuat oleh guru MIPA diperoleh hasil deskripsi soal yang dibuat guru ditinjau dari aspek yang diukur: mengingat $(\mathrm{C} 1)$, memahami $(\mathrm{C} 2)$, menerapkankan (C3), menganalisis (C4), menilai/mengevaluasi (C5), dan mencipta (C6) dapat dipaparkan pada Tabel 1.

Tabel 1. Data kemampuan guru MIPA membuat penilaian pengetahuan ditinjau dari aspek yang diukur.

\begin{tabular}{ccccccccc}
\hline No. & Bidang & Jumlah & \multicolumn{7}{c}{ Aspek yang diukur (\%) } \\
\cline { 5 - 9 } Subyek & & Soal & C1 & C2 & C3 & C4 & C5 & C6 \\
\hline 1 & IPA & 20 & 20,00 & 40,00 & 20,00 & 20,00 & 0 & 0 \\
\hline 2 & IPA & 35 & 28,57 & 37,14 & 20,00 & 14,29 & 0 & 0 \\
\hline 3 & IPA & 30 & 33,33 & 60,00 & 03,33 & 03,33 & 0 & 0 \\
\hline 4 & IPA & 30 & 33,33 & 56,67 & 06,67 & 03,33 & 0 & 0 \\
\hline 5 & IPA & 20 & 10,00 & 70,00 & 5,00 & 15,00 & 0 & 0 \\
\hline 6 & IPA & 30 & 10,00 & 70,00 & 10,00 & 10,00 & 0 & 0 \\
\hline 7 & IPA & 30 & 30,00 & 50,00 & 20,00 & 00,00 & 0 & 0 \\
\hline 8 & IPA & 40 & 27,50 & 57,50 & 10,00 & 05,00 & 0 & 0 \\
\hline 9 & MAT & 40 & 07,50 & 85,00 & 02,50 & 05,00 & 0 & 0 \\
\hline 10 & MAT & 30 & 06,67 & 76,67 & 13,33 & 03,33 & 0 & 0 \\
\hline 11 & MAT & 35 & 05,71 & 91,43 & 00,00 & 02,86 & 0 & 0 \\
\hline 12 & MAT & 40 & 00,00 & 100,00 & 00,00 & 00,00 & 0 & 0 \\
\hline Total & & $\mathbf{3 8 0}$ & $\mathbf{1 7 , 3 7}$ & $\mathbf{6 7 , 9 0}$ & $\mathbf{0 8 , 6 8}$ & $\mathbf{0 6 , 0 5}$ & $\mathbf{0}$ & $\mathbf{0}$ \\
\hline
\end{tabular}

Berdasarkan Tabel 1 dapat dinyatakan bahwa dari 12 perangkat soal MIPA yang dibuat guru yaitu dengan jumlah 380 soal, kemampuan guru membuat penilaian pengetahuan (soal pilihan ganda) masih berada pada aspek pengetahuan mengingat (C1) dan memahami (C2) berturut- 
turut diperoleh $17,37 \%$ dan $67,90 \%$. Menurut Bloom (1971) soal yang yang dibuat pada apek pengetahuan (C1) dan pemahaman (C2) diklasifikasikan sebagai keterampilan berpikir tingkat rendah dalam proses pembelajaran. Selain itu Anderson dan Krathwohl (2010) menyatakan bahwa kemampuan mengingat adalah kemampuan yang diukur dalam hal mengambil pengetahuan dari memori jangka panjang. Sedangkan aspek memahami adalah mengkonstruksi makna dari materi pelajaran, termasuk apa yang diucapkan, ditulis dan digambar oleh guru. Oleh karena itu masih dikelompokkan pada kemampuan berpikir tingkat rendah. Dari data tersebut dapat dikatakan bahwa dalam pembuatan soal MIPA masih banyak pada aspek kemampuan berpikir tingkat rendah.

Sedikit sekali yang membuat soal mengukur pada aspek menerapkan (C3) sebesar 8,68\%, dan menganalisis (C4) sebesar 6,05\%. Masih belum ada soal yang dibuat guru untuk mengukur aspek mengevaluasi (C5) dan aspek mencipta (C6). Hal ini sejalan dengan hasil penelitian yang dilalukan oleh Osnal, Suhartoni, dan Imam W. (2016) dalam meningkatkan kemampuan guru menyusun tes hasil belajar akhir semester melalui Workshop diperoleh bahwa: "guru belum mampu mengukur aspek perilaku (keterampilan) pengetahuan tingkat tinggi berdasarkan Taksonomi Bloom". Hal ini terjadi, karena selama ini guru membuat soal tidak memperhatikan indikator soal namun semata-mata soal yang dibuat berdasarkan referensi yang dipunyai guru saja.
Hasil penelitian didukung oleh Osnal, Suhartoni, dan Imam (2016) yang menyatakan bahwa selama ini guru menyusun tes hasil belajar dibuat dengan mengkompilasi soalsoal dari buku-buku referensi yang dipunyai atau dari kumpulan soal yang sudah ada tanpa mempertimbangkan SK/ KD dan indikator dari RPP yang sudah mereka siapkan. Selaian itu hasil penelitian Mujimin (2010) tentang hasil analisis terhadap soal yang disusun guru SD Islam Terpadu Hidayatullah menunjukkan; soal dengan kategori sukar 6\%, sedang $34 \%$, dan mudah $60 \%$, sedangkan guru SD Negeri Banyumanik 01 membuat soal dengan kategori sukar $6 \%$, sedang $26 \%$, dan mudah $68 \%$.

Belum semua guru memiliki pengalaman menyusun butir soal. Menurut Santyasa (2012) tentang pelatihan asesmen inovatif yang pernah diikuti peserta, sebanyak $33.3 \%$ guru dapat menerapkan dalam pembelajaran, $8.3 \%$ tidak bisa menerapkan dalam pembelajaran, selain itu peserta pelatihan belum pernah mengikuti pelatihan asesmen.

Jika ditinjau dari soal yang dibuat berdasarkan kelompok mata pelajaran IPA dan Matematika, diperoleh hasil analisis sebagai berikut pada Tabel 2 dan Tabel 3 . Dari data pada Tabel 2 diperoleh hasil dokumentasi soal yang dibuat guru dapat dideskripsikan bahwa kemampuan guru kelompok mata pelajaran IPA dalam membuat penilaian pengetahuan (soal pilihan ganda) masih berada pada pengetahuan keterampilan tingkat rendah yaitu aspek pengetahuan mengingat (C1) sebesar 21,59\% lebih tinggi dari rata-rata total $17,37 \%$, 
aspek memahami (C2) sebesar $50,16 \%$ lebih rendah dari rata-rata total $67,90 \%$. Hal ini menunjukkan bahwa pada soal IPA yang dibuat guru lebih banyak soal pemahaman (C2) dari pada mengingat (C1), soal penerapan (C3), dan soal analisis (C4).

Tabel 2. Kemampuan kelompok guru mata pelajaran IPA dalam membuat soal berdasarkan aspek yang diukur.

\begin{tabular}{ccccccc}
\hline \multirow{2}{*}{ Jumlah Soal } & \multicolumn{7}{c}{ Aspek yang Diukur } \\
\cline { 2 - 7 } & $\mathbf{C 1}$ & $\mathbf{C 2}$ & $\mathbf{C 3}$ & $\mathbf{C 4}$ & $\mathbf{C 5}$ & $\mathbf{C 6}$ \\
\hline 20 & 20 & 40 & 20 & 20 & 0 & 0 \\
\hline 35 & 28,57 & 37,14 & 20 & 14,29 & 0 & 0 \\
\hline 30 & 33,33 & 60 & 3,33 & 3,33 & 0 & 0 \\
\hline 30 & 33,33 & 56,67 & 6,67 & 3,33 & 0 & 0 \\
\hline 20 & 10 & 70 & 5 & 15 & 0 & 0 \\
\hline 30 & 10 & 70 & 10 & 10 & 0 & 0 \\
\hline 30 & 30 & 50 & 20 & 0 & 0 & 0 \\
\hline 40 & 27,5 & 57,5 & 10 & 5 & 0 & 0 \\
\hline Jumlah & $\mathbf{1 7 2 , 7 3}$ & $\mathbf{4 0 1 , 3 1}$ & $\mathbf{7 5}$ & $\mathbf{5 0 , 9 5}$ & $\mathbf{0}$ & $\mathbf{0}$ \\
\hline Rata-rata & $\mathbf{2 1 , 5 9}$ & $\mathbf{5 0 , 1 6}$ & $\mathbf{9 , 3 8}$ & $\mathbf{6 , 3 7}$ & $\mathbf{0}$ & $\mathbf{0}$ \\
\hline
\end{tabular}

Tabel 3. Kemampuan kelompok guru mata pelajaran matematika dalam membuat soal berdasarkan aspek yang diukur.

\begin{tabular}{ccccccc}
\hline \multirow{2}{*}{ Jumlah Soal } & \multicolumn{7}{c}{ Aspek yang Diukur } \\
\cline { 2 - 7 } & $\mathbf{C 1}$ & $\mathbf{C 2}$ & $\mathbf{C 3}$ & $\mathbf{C 4}$ & $\mathbf{C 5}$ & $\mathbf{C 6}$ \\
\hline 40 & 7,5 & 85 & 2,5 & 5 & 0 & 0 \\
\hline 30 & 6,67 & 76,67 & 13,33 & 3,33 & 0 & 0 \\
\hline 35 & 5,71 & 91,43 & 0 & 2,86 & 0 & 0 \\
\hline 40 & 0 & 100 & 0 & 0 & 0 & 0 \\
\hline Jumlah & $\mathbf{1 9 , 8 8}$ & $\mathbf{3 5 3 , 1}$ & $\mathbf{1 5 , 8 3}$ & $\mathbf{1 1 , 1 9}$ & $\mathbf{0}$ & $\mathbf{0}$ \\
\hline Rata-rata & $\mathbf{4 , 9 7}$ & $\mathbf{8 8 , 2 8}$ & $\mathbf{3 , 9 6}$ & $\mathbf{2 , 8 0}$ & $\mathbf{0}$ & $\mathbf{0}$ \\
\hline
\end{tabular}

Dari data pada Tabel 3 diperoleh hasil dokumentasi soal yang dibuat guru dapat dideskripsikan bahwa kemampuan guru kelompok mata pelajaran Matematika dalam membuat penilaian pengetahuan (soal pilihan ganda) masih berada pada pengetahuan keterampilan tingkat rendah yaitu aspek pengetahuan mengingat (C1) sebesar 4,97\% lebih rendah dari rata-rata total $17,37 \%$, pada aspek memahami (C2) sebesar $88,28 \%$ lebih tinggi dari rata-rata total $67,90 \%$. Hal ini menunjukkan bahwa pada soal Matematika yang dibuat guru lebih banyak soal 
pemahaman (C2) dari pada pembelajaran Matematika dan IPA mengingat (C1), soal penerapan (C3), ditinjau dari aspek yang diukur dan soal analisis (C4).

Namun demikian, hasil pembuatan soal pada kelompok terdapat perbedaan. Perbedaan ini dapat ditunjukkan pada Gambar 1.

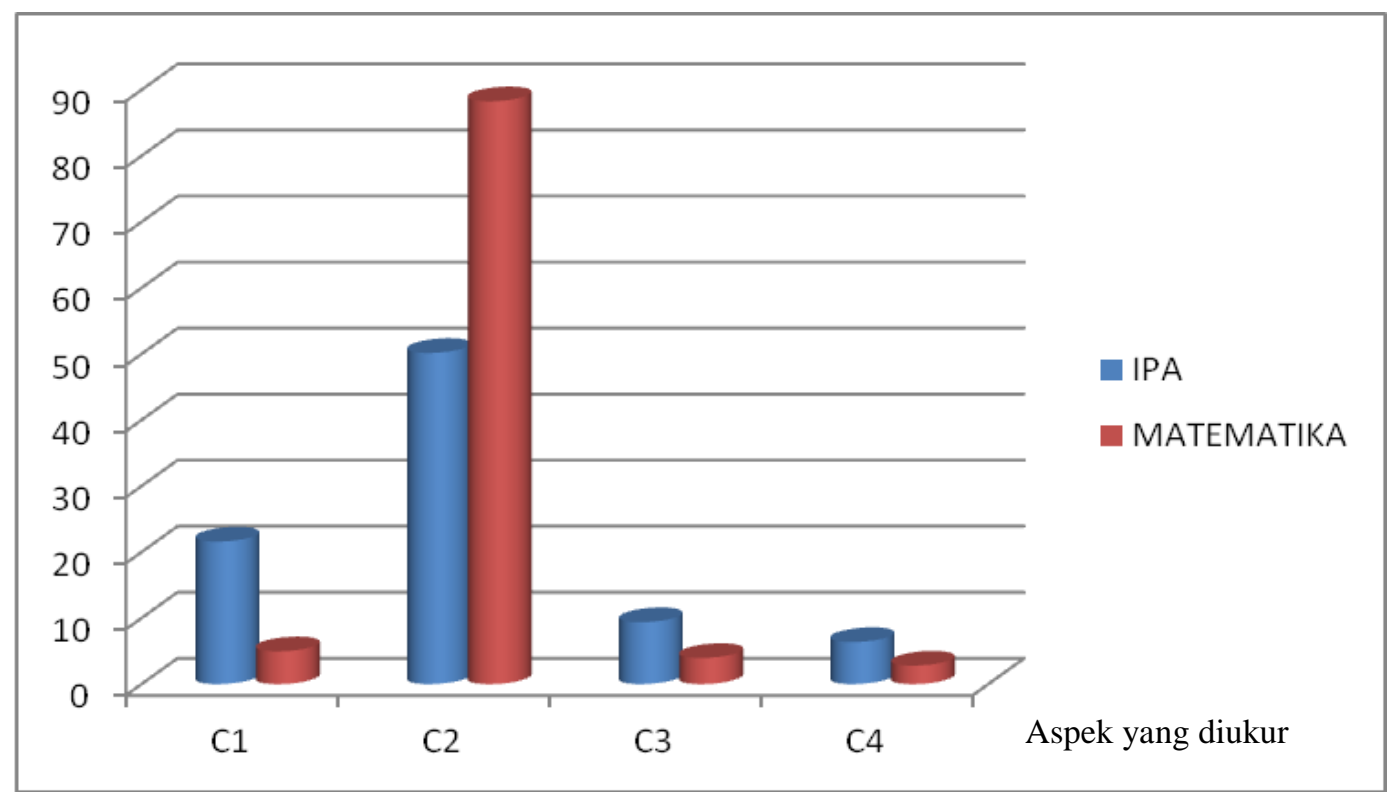

Gambar 1. Perbandingan kemampuan guru ipa dan matematika dalam membuat penilaian pengetahuan berdasarkan aspek yang diukur.

Berdasarkan Gambar 1, jangka panjang atau mengingat. Jika diperoleh gambaran bahwa dihubungkan dengan konsep yang kemampuan guru dalam membuat diukur pada mata pelajaran IPA lebih soal IPA dan Matematika berdasarkan aspek yang diukur antara lain: pada aspek pengetahuan mengingat (C1) soal yang dibuat guru mata pelajaran IPA lebih tinggi dari pada mata pelajaran Matematika, pada aspek pemahaman (C2) soal yang dibuat guru Matematika lebih tinggi dari pada guru IPA. Namun pada aspek penerapan (C3) dan analisis (C4) soal yang dibuat guru IPA lebih tinggi dari pada Matematika.

Hal ini sejalan dengan pendapat Anderson dan Krathwohl (2010) kemampuan mengingat adalah kemampuan yang diukur dalam hal mengambil pengetahuan dari memori tinggi dari pada Matematika, maka konsep IPA lebih banyak tentang fakta dari pada Matematika. Sedangkan aspek memahami adalah mengkonstruksi makna dari materi pelajaran, hasil penelitian menunjukkan kelompok Matematika lebih tinggi dibandingkan kelompok IPA. Karena pada konsep Matematika lebih banyak kearah pemahaman seperti menghitung, menggambar, dan kosep yang termasuk pada apa yang diucapkan, ditulis dan digambar oleh guru.

Sedangkan masih sedikit sekali guru yang membuat penilaian (soal pilihan ganda) pada mengukur 
keterampilan tingkat tinggi seperti aspek mengaplikasikan (C3) baru mencapai $8,68 \%$, dan menganalisis (C4) hanya mencapai 6,05\%. Bahkan masih belum ada yang membuat soal pengetahuan pada aspek menilai/mengevaluasi (C5) atau mencipta (C6). Sejalan dengan pendapat Zohar (2004), dan Teare (2005) menyatakan: aspek analisis, sintesis, dan evaluasi diklasifikasikan sebagai keterampilan tingkat tinggi.

Anderson dan Krathwohl (2010) menyatakan bahwa: pengetahuan keterampilan tingkat tinggi meliputi: mengaplikasikan, menganalisis, mengevaluasi, dan mencipta. Pada dimensi proses kognitif membutuhkan perhatian pada kebutuhan untuk menemukan cara penilaian yang valid dan reliabel, yang juga disebut dengan proses berpikit tingkat tinggi (Ratumanan dan Laurens, 2011).

Selain itu hasil penelitian Suparji (2010), tentang kualitas butir soal buatan guru SMP mata pelajaran Matematika dan IPA di Kabupaten Sumenep diperoleh; tingkat kesulitan butir soal matematika $21,2 \%$ tergolong sulit,16,1\% tergolong sedang, dan $62,7 \%$ tergolong mudah.

\section{SIMPULAN DAN SARAN}

Dari 12 perangkat soal yang dibuat guru yaitu dengan jumlah 380 soal, kemampuan guru membuat penilaian pengetahuan (soal pilihan ganda) diperoleh $17,37 \%$ pada aspek $\mathrm{C} 1,67,90 \%$ aspek $\mathrm{C} 2,8,68 \%$ aspek C3, dan 6,05\% aspek C4. Masih belum ada soal yang dibuat pada aspek C5 dan aspek C6.

Dengan demikian kemampuan guru dalam membuat penilaian pengetahuan (soal pilihan ganda) masih berada pada kemampuan tingkat rendah yaitu aspek mengingat (C1) dan memahami (C2), sedangkan sedikit sekali yang membuat pada kemampuan tingkat tinggi yaitu aspek mengaplikasikan (C3) dan menganalisis (C4). Bahkan masih belum ada yang membuat soal pengetahuan pada aspek menilai/mengevaluasi (C5) atau mencipta (C6).

Ditinjau dari kemampuan guru dalam membuat soal IPA dan Matematika berdasarkan aspek yang diukur antara lain: pada aspek pengetahuan mengingat (C1) soal yang dibuat guru pada kelompok IPA lebih tinggi dari pada Matematika, pada aspek pemahaman (C2) soal yang dibuat guru kelompok Matematika lebih tinggi dari pada guru IPA. Namun pada aspek penerapan (C3) dan analisis (C4) soal yang dibuat guru IPA lebih tinggi dari pada Matematika.

Dengan demikian guru perlu mencoba untuk membuat soal pada aspek yang lebih tinggi terutama pada aspek menganalisis (C4), aspek mengevaluasi (C5), dan aspek mencipta (C6).

\section{DAFTAR PUSTAKA}

Anderson, L, W., \& David R, K. (2010). Kerangka Landasan Pembelajaran, Pengajaran, dan Asesmen, terjemahan Agung Prihantoro. Yogyakarta: Pustaka Pelajar.

Anwar, K., dan Hendra H. (2011). Perencanaan Sistem Pembelajaran KTSP. Bandung: Alfabeta. 
Arikunto, S. (2008). Dasar-dasar Evaluasi Pendidikan. Jakarta: Bina Aksara.

Changelosi, J, S. (1990). Designing Tests for Evaluating Students Achievement. New York: Longman Publishing Group.

Djaali dan Pudji M, P. (2008). Pengukuran dalam Bidang Pendidikan. Jakarta: Grasindo.

Mardapi, D. (2012). Pengukuran Penilaian \& Evaluasi Pendidikan. Yogyakarta: Nuha Medika.

Mujimin. (2010). Kompetensi Guru dalam Menyusun Butir Soal pada Mata Pelajaran Bahasa Jawa di Sekolah Dasar. Diakses 15 Mei 2015 dari http://download.portalgaruda.or g/article.php? article $=137186 \& \mathrm{v}$ $\mathrm{al}=5682$.

Osnal, Suhartoni, dan Imam W. (2016). Meningkatkan Kemampuan Guru dalam Menyusun Tes Hasil Belajar Akhir Semester melalui Workshop di KKG Gugus 02 Kecamatan Sumber Malang Tahun 2014/2015. Jurnal Pancaran, Vol. 5, No. 1, 62-82. Diakses 5 Mei 2016 dari http://jurnal.unej.ac.id/index.ph p/pancaran/article/viewFile/260 4/2098.

Peraturan Menteri Pendidikan dan Kebudayaan Nomor 66 tahun 2013 tentang Standar Penilaian Pendidikan.
Ratumanan, T, G., dan Laurens T. (2011). Penilaian hasil Belajar pada Tingkat Satuan Pendidikan. Surabaya: Unesa University Press.

Santyasa I, W., Nyoman, N., dan Gede, A, S. (2008). Analisis Kebutuhan Pengembangan Model Pelatihan untuk Profesi Guru. Jurnal Penelitian dan Pengembangan Pendidikan. Vol. 2, No. 3, 42-55.

Subroto, S. (1997). Proses Belajar Mengajar di Sekolah. Jakarta: Rineka Cipta.

Sudrajat, A. (2012). Penilaian Hasil Belajar. Diakses 6 September 2015 dari http//akhmad sudrajad.wordpress.com.

Sugiyono. (2008). Metode Penelitian Pendidikan Pendekatan Kuantitatif, Kualitatif, dan $R \& D$. Bandung: Alfabeta.

Suryana S, Fachrudin, dan Ustman. (2010) Pelatihan Asesmen dan Evaluasi Pembelajaran untuk Peningkatan Kemampuan Profesional Bagi Tutor Kejar Paket B Kesetaraan pada Pusat Kegiatan Belajar Masyarakat (PKMB) di Kota Semarang. Jurnal Abdimas, Vol. 14, No. 1. Diakses 7 Juli 2015 dari http://www.lp2m. unnes.ac.id.

Suparji. (2010). "Kualitas Butir Soal Buatan Guru SMP Mata Pelajaran Matematika dan IPA di Kabuopaten Sumenep." 
Jurnal Pendidikan Dasar. Vol. 2, No. 2, 48-52.

Teare, B. (2005). Effective Resources for Able \& Talented Children. New York: Continuum International Publishing Group.
Zohar, A. (2004). Higher Order Thinking in Science Classroom: Studens' Learning and Teachers' Profesional Development. UK: SpringerScience Busness Media BV. 